Schnepel, Burkhard (2018): Guests without a Host: The Indian Diaspora(s) in Mauritius. In: Elfriede Hermann and Antonie Fuhse (eds.): India Beyond India: Dilemmas of Belonging. Göttingen: Göttingen University Press (Göttingen Series in Social and Cultural Anthropology, 12), pp. 131-149. Doi: $10.17875 /$ gup2020-1267

\title{
7 Guests without a Host: The Indian Diaspora(s) in Mauritius
}

\author{
Burkhard Schnepel
}

\section{Introduction}

The ethnohistory and situation of the Indian diaspora in Mauritius today is not only well-documented in archives (see Carter 1996; Deerpalsingh and Carter 1996a, 1996b), it has also been thoroughly studied by a number of scholars. ${ }^{1}$ Therefore, the aim of this chapter is to systematize and analyze the body of knowledge that already exists and situate it within the broader framework of the Indian diaspora. More concretely, I wish to identify seven characteristics particular to 'Persons of Indian Origin' (PIO) in Mauritius, especially in comparison with Indian diasporas elsewhere. These 'particularities' are closely linked with one another and/or build on one another. This is not to claim that one or the other cannot also be found in other Indian diasporas, but both individually and in combination they make the Mauritian case specific. Due to rather than despite this specificity, they may eventually also tell us something about the contestations and strategic maneuvers that individuals and groups in Indian diasporas engage in to make their lives possible, bearable, and even successful elsewhere in the world as well.

\footnotetext{
${ }^{1}$ See, among others, Beejadhur (1995), Benedict (1961), Bissoondoyal and Servansing (1986), Boodhoo (1999), Carter (1995, 1996, 2000), Hazareesingh (1966, 1977), Hollup (2000), Link (2002), Meisig (1999), and Nirsimloo-Anenden (1990).
} 


\section{First Particularity: The Indian Diaspora(s) in Mauritius Has (Have) Many Different Roots and Routes}

The Indian diaspora in Mauritius is manifold and even heterogeneous in its social, caste, class, religious and linguistic respects, and, perhaps most importantly, in places of origin on the Indian subcontinent. Most of the ancestors of today's Indo-Mauritians came to the island as sugar plantation workers ('coolies') under the 'indentured labor' scheme. The scheme was introduced after 1834, when British abolished slavery. ${ }^{2}$ The majority of the Indians shipped to Mauritius (mainly from Calcutta and Madras, but also from Bombay later in the nineteenth century) came from rural areas and belonged to the lowest and poorest castes and classes on the Indian subcontinent. ${ }^{3}$ Later in the nineteenth and twentieth centuries, the 'coolies' were joined by clerks, priests, and merchants from the higher castes and better-off strata of Indian society.

As for their geographical roots, almost two thirds of immigrant laborers (today roughly 700,000 Indo-Mauritians of a total 1.2 million Mauritians) came from the north of India, mainly Bihar and Uttar Pradesh. These people were and are known in Mauritius as Biharis, and they spoke and sometimes speak Bhojpuri, a local north Indian variant of Hindi. Approximately the remaining third came from the south of India, being further divided into Tamil- and Telugu-speaking groups of roughly equal size. The merchants mainly came from western India, so that today three to four percent of the Indo-Mauritians are Marathis and Gujaratis who retain their own group consciousness and language affiliation. ${ }^{4}$ Looking at religion, around $65 \%$ of Mauritius's PIOs are Hindu, 25\% Muslim, and 10\% Christian, with many Tamils especially having converted to Christianity. Within these categories there are also various, sometimes quite important further sub-distinctions, such as between orthodox Hindus and Arya Samaj Hindus, ${ }^{5}$ Sunni and Shiite Muslims, ${ }^{6}$ and Catholics, Protestants and Pentecostals. However, Hollup (1994: 300) prefers a categorization based on what he calls "ethnic populations." According to his estimates (based on the 1972 and 1983 censuses), Hindus make up $40.2 \%$ of the total Mauritian population (58\% of PIO), Tamils $7.3 \%$ (10.5\%), Telugus 3.0\% (4.3\%), Marathis $2.1 \%$ (3.1\%), and Muslims $16.6 \%$ (24\%). These various regional backgrounds, mother tongues and ethnic and religious identifications combine dynamically with other

\footnotetext{
${ }^{2}$ On indentured labor, see especially Tinker (1974). Carter (1996), who seeks to offer a balanced picture of indentured migration by discussing both the cruelties and the opportunities it offered, pointedly calls it "a rescue package for sugar plantations" (1996: 19).

3 On the situation in India, see Carter (1992) and Prakash (1992).

${ }^{4}$ On Gujarati merchants in Mauritius, see Kalla (1987).

5 On the Arya-Samaj in Mauritius, see Hollup (1995) and Ramsurrun (2001).

${ }^{6}$ On Muslims in Mauritius, see Donath (2009), Hollup (1996), and Jahangeer-Chojo (1997, 2002).
} 
identity-making and identity-unmaking criteria, such as education, a rural-urban divide, and differences in economic success and professional standing. ${ }^{7}$

One should therefore be cautious in speaking of the Indian diaspora in Mauritius as a homogenous group. Rather, we should think of a plurality when it comes to describing and analyzing the internal socio-cultural, politico-economic, and religious aspects of the Indo-Mauritian diaspora(s). However, more important than these statistics is that Indo-Mauritians themselves often strategically emphasize and adopt different identities in different situations. Thus, in some situations - and in structural opposition to the other, non-Indian, inhabitants of Mauritius, as well as the island's Indo-Muslims - some PIOs may stress that their 'ancestral language' is Sanskrit and their religion Hindu, while in other situations Hindus and Muslims may point to their common Indian origin as opposed to fellow Mauritian nationals with African, Chinese, or French roots. In yet other situations, when it comes to defending their social, educational and economic privileges, well-off or well-educated Indians may ally with Gens-de-Couleurs and/or Franco-Mauritians of similar standing, at the expense of solidarity with rural and poor Indo-Mauritians. In other situations, internal differences may fall away, not only within the community of Indo-Mauritians, but between all ethnic groups and other communities living on Mauritius, as when Mauritius has an important soccer match against Réunion, or when relations between Mauritians and tourists are at stake. ${ }^{8}$

In a nutshell, PIOs in Mauritius adopt multiple, overlapping, and situationally shifting 'fusion-and-fission' forms of identification, both within the category of Indo-Mauritian and when transcending this category, for example, when they see themselves as belonging to larger entities such as the Mauritian nation, or as Asians, or even as Creoles (e.g. when the southwest Indian Ocean is compared and aligned with the history and the state of affairs in the Caribbean). Some of these identifications, namely those derived from the region of origin on the Indian subcontinent, or those referring to the three main religions or language markers on Mauritius, are more important from the actors' points of view than others, and therefore tend to be 'essentialized' more strongly.'

\section{Second Particularity: Indo-Mauritians Have Established a New Life Relatively Close to 'Home'}

In the nineteenth century, 'coolies' were better off than African slaves, who were forcibly deported in chains, in terrible hygienic conditions, and under severe penal

\footnotetext{
7 In addition, an estimated 5\% of Indian emigrants to Mauritius were adivasis or tribals. See Hollup (2000: 222).

${ }^{8}$ On the socio-cultural and economic impact of tourism on Mauritius, see Schnepel and Schnepel (2008, 2009a) and Schnepel (2009).

9 Plantation owners did not hesitate to make use of inner-Indian ethnic cleavages to 'divide and rule.'
} 
regimes. The average death toll on vessels transporting Indian laborers was around three to five percent, while the death toll for slaves had been roughly ten percent. Certainly three to five percent is bad enough, and is therefore an advantage clearly to be understood in relative terms. Indian 'coolies' were also crammed into inhuman and unhygienic spaces on often old and unsafe vessels at risk of shipwreck, and were prone to the spread of epidemic diseases (see Carter 1996: 45-47). The disruptive journey through which family, neighborhood and friendship ties were severed for a long time, if not forever, as well the potentially bleak and insecure life in an unknown and often hostile world, placed a severe mental burden on those who journeyed across the 'black waters' (kala pani) to new shores. ${ }^{10}$ Once safely there, communication with and remittances to families back home in India were uncertain, and a return journey would only be possible, if at all, after the standard five-year contract had been completed.

A journey to Mauritius took around eight weeks from Calcutta and six weeks from Madras or Bombay (see Carter 1996: 32). The passage to Mauritius was therefore long and hard compared to that to Sri Lanka and Burma. Moreover, from Sri Lanka and Burma it was easier to return to India frequently and to maintain some ties with home, and there it was also possible to be joined by members of one's family, caste, village, and sub-region on a larger scale. This made it possible to try and 'copy' one's socio-cultural life at home, with all its established networks of solidarity and its traditional caste-based social organization. This socially more integrated system of migration was known as kangani. ${ }^{11}$ In contrast, trips to Mauritius were by and large made by individuals, rather than being family, sub-caste or village affairs. While on board, one might meet neighbors or friends, or make new friends. These new relationships became known as jehaji bhai or 'ship brothers,' and later on the island, they could assume the character of quasi-kinship bonds. ${ }^{12}$

Nevertheless, compared to other destinations in the world-wide indentured labor scheme, ${ }^{13}$ Mauritius was still relatively close to home. South and East African destinations as well as Malaysia were just a week or two further away and may be

${ }_{10}$ Moreover, Carter (1996: 51) estimates that around thirteen percent of immigrants died during their first five years on the island.

${ }^{11}$ On the kangani system of importing labor, see Jain (1993: 6-11).

12 The issue of caste in Mauritius deserves a separate discussion that would go beyond the scope of this article. Here it suffices to state with Hollup: "Among the Hindus of Mauritius, there is no system of hierarchically ordered groups, but caste populations still exist as kinship groups, although the endogamous groups have undergone considerable change" (1994: 298). See also Hollup (2000).

${ }^{13}$ In all, approximately 1.5 million Indians left India as contract laborers before 1914, according to Carter (1996: 20, 22) and Tinker (1974: 62, 114). These numbers are roughly distributed as follows: Kenya 32,000; Seychelles 6,315; Reunion 26,000; South Africa 152,184; Fiji 60,965; Mauritius 453,063; Jamaica 36,412; Guadeloupe 43,326; Martinique 25,509; Trinidad 143,939; British Guiana 238,909; Dutch Guiana 34,304; Grenada 3,200; St. Vincent 2,472; St. Lucia 4,350. In this scheme, Mauritius not only received the largest number of contract laborers, it was also the first such destination. In many ways, Mauritius was used as an experiment and model for other countries. See McPherson (2009). 
comparable in this respect. Destinations in the Caribbean or Fiji were so much further away (19 to 20 weeks on board) that these longer distances made a significant qualitative difference.

Indo-Mauritians who had completed their time as contract laborers could return to India, and about a third did so. However, many of these returnees did not stay in India, but re-emigrated to Mauritius, this time bringing their wives and families with them. The relative proximity of Mauritius to the Indian homeland, accompanied by the gradual improvement of postal communications and maritime transport, therefore enabled a sort of circular or chain migration to develop. The significant number of those who stayed in Mauritius, the ever-increasing number of new arrivals (among them many re-emigrants with their wives and families), and the increasing number of female coolies (which resulted in marriages and island-born offspring) ${ }^{14}$ all gradually resulted in the establishment of more traditional forms of social cohesion among Indo-Mauritians and, as we shall see in the next 'particularity', in the important numerical strength of PIOs on Mauritius.

\section{Third Particularity: The Indian Diaspora in Mauritius is Substantial in Absolute Numbers, but Even More So in Relative Numbers}

It is estimated that more than twenty million Indians live abroad today, as reflected in the statistics shown in the table next page. Two major historical waves of Indian emigration are largely responsible for these numbers. ${ }^{15}$ The first wave consisted of migration in the nineteenth century to the plantation economies in southern, subtropical parts of the world. The second wave, starting after 1945 and arguably still continuing, has brought Indians to the industrialized countries of North America and Europe, as well as to Australia and, for several decades now, to the oil-producing Arab world. By and large, the descendants of those who came with the first wave are today regarded as Persons of Indian origin or PIO, while substantial numbers of those who came with the second wave or their descendants are Non-Resident Indians or NRIs.

The Indian diaspora on Mauritius is substantial, and exceeded in absolute numbers only by those in Great Britain, Canada, Malaysia, Myanmar (Burma), Saudi Arabia, South Africa, the USA, and the United Arab Emirates. However, only Malaysia and Myanmar - two countries with their very own special kangani histories -

\footnotetext{
${ }_{14}$ Towards the 1870 s, it was made obligatory to have at least $40 \%$ of women on coolie-ships. At the end of the century, Indians born locally on Mauritius started to outnumber new immigrants (Carter 1996: 149).

${ }^{15}$ For overviews, see among others Jain (1993), Schnepel (2005), van der Veer (1995), and Vertovec (2000).
} 
Table: Estimated Size of Overseas Indian Community

\begin{tabular}{|c|c|c|c|}
\hline Land & $\begin{array}{l}\text { Persons of Indian } \\
\text { Origin (PIO) }\end{array}$ & $\begin{array}{l}\text { Non-Resident } \\
\text { Indians (NRI) }\end{array}$ & Total \\
\hline Australia & 160000 & 30000 & 190000 \\
\hline Bahrain & nil & 130000 & 130000 \\
\hline Canada & 700000 & 150000 & 850000 \\
\hline Fiji & 337000 & nil & 337000 \\
\hline France & 55000 & 10000 & 65000 \\
\hline Germany & 10000 & 25000 & 35000 \\
\hline Great Britain & & & 1200000 \\
\hline Guadeloupe & 40000 & nil & 40000 \\
\hline Guyana & 392000 & nil & 392000 \\
\hline Italy & 36000 & 36000 & 72000 \\
\hline Jamaica & 60000 & 1500 & 61500 \\
\hline Kenya & 85000 & 15000 & 100000 \\
\hline Kuwait & 1000 & 294000 & 295000 \\
\hline Malaysia & 1600000 & 15000 & 1615000 \\
\hline Mauritius & 705000 & 11000 & 716000 \\
\hline Myanmar & 2500000 & 2000 & 2502000 \\
\hline Netherlands & 200000 & 15000 & 215000 \\
\hline Oman & 1000 & 311000 & 312000 \\
\hline Qatar & 1000 & 130000 & 131000 \\
\hline Réunion & 220000 & nil & 220000 \\
\hline Saudi Arabia & nil & 1500000 & 1500000 \\
\hline Singapore & 217000 & 90000 & 307000 \\
\hline South Africa & & & 1000000 \\
\hline Surinam & 150000 & nil & 150000 \\
\hline Tanzania & 85000 & 5000 & 90000 \\
\hline Thailand & 70000 & 15000 & 85000 \\
\hline Trinidad \& Tobago & 500000 & nil & 500000 \\
\hline United Arabian Emirates & 50000 & 900000 & 950000 \\
\hline USA & & & 1700000 \\
\hline Yemen & 100000 & 1000 & 101000 \\
\hline
\end{tabular}

These figures have been selected from the more detailed information "Estimated Size of Overseas Indian Community: Countrywise" found in Ministry of External Affairs (2002: xlvii-xlx). 
had larger first wave immigration. Furthermore, in relation to the total population, the Indian diaspora in Mauritius holds the top position, with more than two-thirds of the population having an Indian background.

With the gradual democratization of Mauritian society from the first half of the twentieth century onwards, and the granting of full electoral and citizenship rights today, ${ }^{16}$ this demographic dominance has allowed Indians great political influence, and even assured their dominance within the Mauritian political system. Indeed, with the exception of Paul Berenger, a left-wing Franco-Mauritian who led the country for periods in the 1990s and 2000s, all Mauritian prime ministers have had an Indian background. This numerical and subsequent political superiority was accompanied, if not also decisively triggered and supported, by the gradual economic liberation and upward social mobility of PIOs in Mauritius. Today, substantial numbers of Indo-Mauritians are well-off and highly educated, and are thereby 'upwardly mobile' citizens. Therefore, the politico-economic and social standing of contemporary Indo-Mauritians has improved greatly when compared not only with their initial state of 'coolitude,' but also with the descendants of their former relatives and neighbors who chose to stay behind in India. ${ }^{17}$

\section{Fourth Particularity: The Indian Diaspora in Mauritius Is Not the Only One There}

According to the 1982 census (the last of its kind), the population of Mauritius totaled 1.2 million people, and was categorized as follows: Hindus 52\%; Muslims $16 \%$, Sino-Mauritians 3\%, and General Population 29\%. Even at first glance, therefore, it is obvious that Mauritius is a multi-ethnic and poly-religious society. This diversity is expressed by the 20 annual nationwide holidays which demonstrate that most religious and ethnic groups on the island are equally acknowledged and their interests and self-esteem are respected. Another symbol of plurality (and unity in diversity) is the national flag, which features an abstraction of the colors of the rainbow. ${ }^{18}$

If we look at the categorizations used in the census more carefully, some incongruities appear. The distinction between Hindus and Muslims is obviously a religious

\footnotetext{
${ }^{16}$ On democratization processes and ethnic politics in Mauritius, see Bräutigam (1997), Carroll and Carroll (1999 and 2000), Mathur (1997), and Mukonoweshuro (1991).

${ }_{17}$ For the economic development of Indo-Mauritians, see Allen (1999: chapter 6), Carter (2002), Carter, Deerpalsingh and Govinden (2000), Metha (1995), and Srebrnik (1999).

${ }_{18}$ For the demographic development of Mauritius, see Lutz (1994), Dinan (2003), and Royle (1995). The difficulty of categorizing sections of the Mauritian population into clearly defined and 'politically correct' groups is expressed by the fact that, during more than a century of state-run census activities, a number of different criteria were tested and rejected until, in 1982, all such endeavors were discarded. See Christopher (1992).
} 
one, and we have already noted that the ancestors of both Hindus and Muslims in Mauritius today originally came from India, especially North India. However, given that various Muslim groups on the island have recently started to claim that they originate from the Arabian peninsula and to call Arabic (not Hindu or Urdu) their 'ancestral language,' these common local roots in India should again be emphasized. Hence, both Hindus and Muslims are Indo-Mauritians and were actually labelled as such in censuses until 1947, the year of India's independence and the partition into India and Pakistan. However, the third largest census group, 'Sino,' was not a religious categorization but rather one based on region of origin, namely China or East Asia. This group could be subdivided into Hakka and Cantonese speaking Chinese. Subsumed under the 'General Population' label are such heterogeneous groups as white Franco-Mauritians (accounting for 2\% of the population), 'Creoles' (in the Mauritian context the descendants of African slaves) and 'Coloureds' or 'Gens de coleur' (a hybrid category denoting the offspring of mixed, usually 'black' (female) and 'white' (male) unions who were barred from inheriting their father's estates but often received better education and other privileges, allowing them to climb the social ladder). ${ }^{19}$ Strikingly, the descendants of former slaves and former masters now found themselves in the same demographic melting pot, one called 'General.' This indicates that, in post-colonial Mauritius, the descendants of indentured laborers had become such a majority that they could be split into two religious groups and also be distinguished from the East Asian 'Sino-group.' The unified category of 'General Population,' made up of the two distinct groups that first populated the island in the eighteenth century, can therefore be defined negatively, as all those who did not come from Asia.

Using other categorizations in the census would obviously have produced different figures. Taking regions of origin, for example, a census would have identified macro-groups as Indian, Chinese, French and African, or Europeans, who could be distinguished from Africans and Asians. If one took religion in all instances (and not only in the first two) as the criterion, the cards would have been substantially re-shuffled: not only are all sub-groups of the 'General Population' Christians, whether black, white or colored, but so are large numbers of Mauritians hailing from South India (probably subsumed under the label 'Hindu' in 1982), as well as most Sino-Mauritians. ${ }^{20}$ Taking yet another criterion, namely that of language, would have made things both easier and more complicated. Officially, fifteen languages are spoken in Mauritius, including English, French, Kreol, Bhojpuri, Hindi, Urdu, Tamil, Telugu, Marathi, Arabic, Hakka, and Cantonese. However, in almost all interactions, a French-based Kreol is spoken, and occasionally French. Indeed, many Mauritians speak excellent French, with most of the national media also communicating in French. The official national language, however, is neither French nor

\footnotetext{
19 Numerous 'Gens de Coleur' today are lawyers, teachers, surgeons, journalists, managers, or in similar 'middle-class' positions.

${ }^{20}$ On religion as an 'identity marker,' see especially Eriksen (1998: 90-97).
} 
Kreol, but English, though (or perhaps precisely because) only a minority of educated Mauritians master the language and enjoy using it. If one looks at language less as a means of communication than as a symbolic marker of identification and belonging, another dimension is added. Asked about their ancestral language or mother tongue, Indo-Mauritians in particular tend to mention languages such as Sanskrit, Hindi, Urdu and even Arabic, which their ancestors could barely have spoken when they arrived. This seems strange because few Indo-Mauritians have these as their native languages today, nor would have many of their ancestors or 'mothers.' While speaking Kreol in everyday life, some other Indo-Mauritians today also speak Hindi, Marathi, Bhojpuri or Urdu at home and/or as a second language in community affairs. However, for reasons of identity politics, Indo-Mauritians would not call Kreol, the language of the Creoles, their 'mother tongue. ${ }^{21}$

In Mauritius then, we find multiple, sometimes overlapping, sometimes structurally opposed identities in action and motion. Hence, Mauritius represents a quite heterogeneous conglomeration of groups, which can be classified in a number of ways, according to country or continent of origin, phenotypical characteristics, (claimed) ancestral languages, religious denominations, and socio-cultural or economic characteristics. Among these various groups on the island, PIOs constitute the majority: about two-thirds when all Indo-Mauritians are considered, and still more than $50 \%$ when only Hindus are counted. As I pointed out in 'Particularity Number One,' these PIOs can be further differentiated or divided along various lines when different criteria are applied, not only analytically (from the point of view of an outside observer), but also by the actors themselves in their dynamic and strategic responses to various situations. This fluid and shifting situation applies not only to the PIOs, but also to other groups on the island. In Eriksen's words: "The main theoretical point here is that ethnicity is, in practice, not an inert, categorical property of persons (although folk models tend to depict it as such), but a property of the relationship between agents acting in situations and contexts and as such, its meaning changes with the context" (1998: 98-99). ${ }^{22}$

\section{Fifth Particularity: All Mauritians Come from Elsewhere and Value Their Diasporic Links}

The fifth particularity arises out of the fourth one, but it adds another particular dimension to the overall diasporic state of affairs in Mauritius discussed so far: each and every sector of the multi-ethnic Mauritian 'rainbow' population has come from elsewhere. This means that no single group living on Mauritius today can claim

\footnotetext{
${ }^{21}$ Several studies discuss the importance of language identification in politics in contemporary Mauritius. See, among others, Eisenlohr (2001, 2002, 2004, 2009), Hookoomsing (1986), Eriksen (1990, 1998: 75-90), and Hookoomsing, Ludwig and Schnepel (2009), Ludwig and Schnepel (2009).

${ }^{22}$ On the issues in this section, see especially Eriksen (1998: 14-21, 47-74, 97-101).
} 
indigeneity and hence demand rights or privileges arising from such a claim. Some groups may have been there before others or even claim to have come first. However, today any such claim to have been 'earlier comers' or 'first settlers' is less important than sheer numbers, which eventually translate into political power. The absence of any aboriginal or officially acknowledged first-comer population makes present-day inter-ethnic negotiations and identity politics somewhat unique. On Mauritius, no group can make a native claim to possession or at least privileged access to land or a resource, as we may find in Australia, the United States, or (even more comparable to the Mauritian situation) in Fiji, where Fijian groups have sought to bar the descendants of coolies from acquiring land property on the basis that only ethnic Fijians are the 'sons of the soil,' or in Trinidad, where Afro-Trinidadians claim political privileges on account of having arrived on the island first. ${ }^{23}$

Although, or maybe exactly because, everyone on the island originally came from elsewhere, ${ }^{24}$ the idea and ideology of an original home elsewhere remains pertinent in most contemporary Mauritians lives, whether socially, politically, economically or religiously. In other words, apart from being Mauritians and Mauritian nationals (which they are and consider themselves to be), all sections of Mauritian society also consider themselves, sometimes quite significantly, as having diasporic roots and continuous diasporic links to their real and/or assumed 'homelands.' Consequently, in both ideology and practice they exhibit and are guided by a diasporic consciousness. This is complicated by the fact that, after several decades of secondary migrations starting from Mauritius, there are now also Mauritian diasporas, some of them Indo-Mauritian diasporas, most prominently in countries like Australia, South Africa, England, or France.

\section{Sixth Particularity: The Mauritian Kind of Nationalism Can Be Called 'Ethnonationalism'}

The diasporic consciousness and politics are supported by the state in both internal and external policies. In Mauritius, the idea of nationhood and the state differs radically from the nineteenth-century West European prototype of 'one culture/one language/one religion/one nation/one territory/one state.' While this 'ideal' nation was seldom if ever achieved elsewhere, after independence in 1968 Mauritius had to confront its racial, socio-cultural, linguistic, and religious diversity. Attempts to build the nation and unify its elements into both a working unit and a sentimental entity had to be modelled on the well-known slogans 'unity in diversity' and the 'rainbow nation.' 25

\footnotetext{
${ }^{23}$ On this point, see Carroll (1994), Eriksen (1992) and Srebnik (2000: 10-11).

${ }^{24}$ This observation also applies to most of the species of flora and fauna to be found on the island today.

25 The issue of nation-building in Mauritius against the background of ethnic plurality and strong eth-
} 
In other words, the Mauritian nation-state had to harmonize two issues which often conflict in countries around the world. On the one hand, there was the great importance that Mauritians gave and still give to their ethnicity and roots. On the other hand, there has been an urgent need to build a unified nation in which divergent interests and identity markers are peacefully and effectively brought together under one umbrella, and with a number of 'common denominators' (Eriksen 1998). So far the goal of accommodating two (for many apparently contradictory) ideologies and community-building principles has been achieved with great success. In economic terms, Mauritius has had its up and downs and its inequalities, but by and large this neoliberal 'tiger state' can boast remarkable achievements, which are no longer based solely on sugar but on a cleverly diversified economy and a powerful 'hub strategy.' Furthermore, Mauritius has managed to establish and practice a rather consensual multiparty democracy (see Nave 2000), making it "one of the few stable democracies in the postcolonial world" (Eriksen 1998: 6). Socially, despite all the conflicts of interest and communal contestations around resources, there have been relatively few cases of violent unrest since 1968, with each of these ending within days. Furthermore, these upheavals were not necessarily based on and motivated by ethnic interests, and may be better understood as youth revolts, ${ }^{26}$ or economic or class struggles.

While the Western European ideal of nationhood remains globally dominant today, Mauritius is certainly not alone in having to build the nation along other lines. In fact, the unity-in-diversity paradigm also guides other post-colonies like India and Indonesia. Indeed, after independence many other postcolonial nation-states have found either that their territorial borders had been drawn arbitrarily, cutting across ethnic and cultural groups, or that, within the framework of the new nations, a multitude of heterogeneous groups had found themselves mingled together in the new nation, or that their migrant populations had been 'shipped together' without any consideration of socio-cultural, linguistic, or religious characteristics.

The Mauritian state's policy of (multi)ethno-nationalism instead of mono-nationalism, therefore, only becomes unique if we add two other aspects to the mix. First, all ethnic identifications on the island are closely combined with and based on diasporic imaginations: ethnic discourses in Mauritius always emphasize links to other parts in the world, to other homelands. The second aspect, which makes this sixth particularity unique in a discussion of Indian diasporas, leads us directly to the last 'particularity.'

nic consciousness is exemplarily discussed in Eriksen (1998, especially pp. 137-166). See also ChazanGillig (2000).

${ }^{26}$ This was most obvious in the 1999 riots, the last serious riot in Mauritius, when there were clashes between young people of all ethnic backgrounds and the police after the famous reggae/seggae musician Kaya had died under suspicious circumstances in police custody. 


\section{Seventh Particularity: The Role Model for Ethnic-Cum-Diasporic Identity on Mauritius Is Provided by the Indian Diaspora, Especially Its Hindu Variant}

To repeat, nation-building activities and national ideologies on Mauritius are based on the idea of the legitimate existence of a number of different ethnic groups, which are generally represented and ideally share power in proportion to their relative numerical strength. The diversity of origins of these ethnic groups means that they all share a diasporic consciousness (to some degree) and logic in which the following (interconnected) elements are given esteem and value:

- an established link to a homeland outside Mauritius

- an ancestral language

- an ancient and essentialized 'ancestral culture'

- a religion, which is conceived as 'traditional' and regularly performed and expressed in major religious festivities

- a known history of one's own, accompanied by markers of 'cultural heritage.'

As I stated, all ethnic groups share these diasporic evaluations more or less. I must now stress, however, that these elements are best achieved by the Hindu diaspora in Mauritius, where a sacred dimension is attached to each element. To put it the other way round, perhaps more accurately, the Indo-Mauritian version of diaspora has become so dominant that it serves as the model and ideal for other ethnic groups as well. Let us look at these elements once again, this time with a focus on the Indian diaspora:

- Indo-Mauritians can clearly identify India - 'Mother India,' that is - as their original and sacred land of origin.

- Hindi and Sanskrit are conceived of and propagated as mother tongues, representing purity and even sacredness.

- Indian philosophy, literature, music, and dance are considered ancient and sacred, and there are various institutions in Mauritius, some of them sponsored from India, which offer venues and platforms for their performance.

- Hinduism, with its daily rituals and major religious festivals, plays an important role in Mauritian public life. Some festivals, like Divali in November or the Maha Sivaratri in February, are nationwide holidays.

In this Indo-Mauritian logic of diaspora, the Muslim part of the Indo-Mauritian community finds itself somewhat included or encompassed. In this ideal type and 
model, the Indian diaspora - which I show in Particularity 2 to be manifold and even heterogeneous in itself - is a Hindu diaspora.

This Hindu model represents the ideal, but it is seldom achieved by all. This is evident, especially, in how Mauritians of African origin fare in these respects. As far as their country of origin is concerned, Africa is too large to qualify as a sentimental 'home country.' The violent abduction of their ancestors from concrete territorial roots, and the subsequent roots- and identity-extinguishing condition of slavery have severed any factual links to specific countries, ${ }^{27}$ and have also dampened any emotional and ideational attachments to them. Moreover, in the media contemporary Africa is typically represented as a place of poverty, misery, corrupt regimes and war, making it even more difficult for Afro-Mauritians to attach positive evaluations to their 'ancestral homes.' In terms of language identity, slavery has also cut the ties to any mother tongue. Certainly, Mauritian Creole or 'Morisyen,' contains significant Bantu elements, but even its practitioners conceive of it (wrongly or not ${ }^{28}$ ) as a derivative form of French rather than an ancestral language. Therefore, Creole hardly qualifies as an ethnic marker for Afro-Mauritians, let alone a sacred one. In religious matters, most Creoles are Christians today. There are few 'African' elements in the praxis of the religion, which was introduced by the colonists and the former slave masters. Culturally, Mauritians clearly identify the Sega dance as Creole rather than African in origin, and see it as a cultural product that only emerged in Mauritius under the harsh conditions of slavery. ${ }^{29}$

From the point of view of Hindu nationalists and their dominant idea of diaspora, then, the Mauritian descendants of former African slaves serve as an example of how culture and cultural identity can be lost if one's roots are severed and/or forgotten. So, all in all, the second largest group in Mauritius (around 25\%), namely Mauritian Creoles, is generally seen as a deficient and incomplete version of the (Hindu) ideal of diaspora. This is strikingly expressed by the categorization of Creoles in past censuses under 'General Population' (as I pointed out above), rather than being recognized as an independent and clearly identifiable entity in their own right. ${ }^{30}$

\footnotetext{
${ }^{27}$ Certainly, Afro-Mauritians are sometimes called Malgas or Mozambik, referring to an assumed origin from Madagascar and Mozambique, but these designations are meant pejoratively. It is estimated that about $45 \%$ of all slaves came from Madagascar, but many of these may have come first come to Madagascar from elsewhere. See Eriksen (1998: 52) and Allen (1999: 42).

${ }^{28}$ Linguists have investigated and discussed this point in great detail.

29 On Mauritian Sega, see Schnepel and Schnepel (2009b, 2011).

${ }^{30}$ On this and other aspects of the so-called 'Creole malaise,' see especially Miles (1999).
} 


\section{Conclusion}

Since the mid-1990s, India has shown an increasing interest in its diasporas spread across the world. This interest has been accompanied by a number of legal, fiscal, economic, political, and socio-cultural measures, which have substantially changed interactions and exchanges between 'Mother India' and her 'children.' Indo-Mauritians have also been affected by this new policy. The introduction of a 'Persons of Indian Origin Card' in particular - which is valid for twenty years and offers many advantages for PIO (making their status comparable to that of NRIs) - has succeeded in strengthening relations between Indo-Mauritians and India (see Kantowski 2002).

The numerical predominance of PIO in Mauritius, the opening of India to PIO and NRIs, and the ever-increasing economic power and attractiveness of India in a globalized world have led to 'Indian-ness,' especially in its dominant form 'Hinduness', increasing in strength in Mauritius and in India. Consequently, Mauritius has strengthened its relationship with India on all levels, not just an economic one. The increasing interest of 'Mother India' in their NRI and PIO 'children' all over the world (and especially in their remittances) has been accompanied by Mauritian PIO's increasing interest in India and their roots there. This search for roots takes on many forms and manifestations, such as numerous individuals of Indian background visiting the Mahatma Gandhi Institute to search for archival documents relating to their ancestors.

All these particularities, individually and in sum, create a special position for the Indian diaspora in Mauritius. The Indian diaspora(s) in Mauritius, as well as the other diasporas (African, Chinese, French, English) on the island, could be called 'guests without a host.' However, if a diasporic group such as the Indian (especially the Hindu) one does manage to achieve numerical superiority, if no other group has traditional claims to land, resources or privileges, and if this diasporic group also achieves some kind of social and politico-economic standing and educational skills, then it can flourish. In a democratic environment it can even become so dominant that it turns from being a 'guest without a host to becoming the 'host.' This process can be facilitated by the original home country, if it discovers the potential its diaspora(s) has to offer. All this was the case for the Indian diasporas in Mauritius, especially for the Hindu one. 


\section{References}

Allen, Richard B. 1999. Slaves, Freedmen, and Indentured Laborers in Colonial Mauritius. Cambridge: Cambridge University Press.

Beejadhur, Aunauth. 1995. Indians in Mauritius. Quatre Bornes, Mauritius: Pandit Ramlakhan Gossagne Publications.

Benedict, Burton. 1961. Indians in a Plural Society: A Report on Mauritius. London: Her Majesty's Stationery Office.

Bissoondoyal, U., and S. B. C. Servansing, eds. 1986. Indian Labour Immigration. Moka, Mauritius: Mahatma Gandhi Institute.

Boodhoo, Sarita. 1999. Bhojpuri Traditions in Mauritius. Port Louis: Mauritius Bhojpuri Institute.

Bräutigam, Deborah. 1997. "Institutions, Economic Reform, and Democratic Consolidation in Mauritius." Comparative Politics 30 (1): 45-62. doi:10.2307/422192.

Carroll, Barbara W., and Terrance Carroll. 1999. "The Consolidation of Democracy in Mauritius." Democratization 6 (1): 179-97. doi:10.1080/135103499 08403602.

- 2000. "Accommodating Ethnic Diversity in a Modernizing Democratic State: Theory and Practice in the Case of Mauritius." Ethnic and Racial Studies 23 (1): 120-42. doi:10.1080/014198700329150.

Carroll, Terrance. 1994. "Owners, Immigrants and Ethnic Conflict in Fiji and Mauritius." Ethnic and Racial Studies 17 (2): 301-24. doi:10.1080/01419870 .1994.9993826.

Carter, Marina. 1992. "Strategies of Labour Mobilisation in Colonial India: The Recruitment of Indentured Workers for Mauritius." Journal of Peasant Studies 19 (3-4): 229-45. doi:10.1080/03066159208438494.

-1995. Servants, Sirdars, and Settlers: Indians in Mauritius, 1834-1874. Delhi: Oxford University Press.

- 1996. Voices from Indenture: Experiences of Indian Migrants in the British Empire. London: Leicester University Press.

—, ed. 2000. Across the Kalapani: The Bihari Presence in Mauritius. Port Louis: Centre for Research on Indian Ocean Societies.

- 2002. "Subaltern Success Stories: Socio-Economic Mobility in the Indian Labour Diaspora: Some Mauritian Case Studies.” Internationales Asienforum 33: 91-100.

Carter, Marina, S. Deerpalsingh, and V. Govinden. 2000. “The Making of a New Community: Socio-Economic Change and the Bihari Hindus." In Across the Kalapani: The Bihari Presence in Mauritius, edited by Marina Carter, 101-18. Port Louis: Centre for Research on Indian Ocean Societies.

Chazan-Gillig, Suzanne. 2000. "Ethnicity and free exchange in Mauritian society." Social Anthropology 8 (1): 33-44. doi:10.1111/j.1469-8676.2000.tb00205.x. 
Christopher, A. J. 1992. "Ethnicity, Community and the Census in Mauritius, 1830-1990." The Geographical Journal 158 (1): 57-64. doi:10.2307/3060017.

Deerpalsingh, Sarojini, and Marina Carter, eds. 1996a. Select Documents on Indian Immigration. Mauritius, 1834-1926: Vol. 2: The Despatch and Allocation of Indentured Labour. Moka, Mauritius: Mahatma Gandhi Institute.

_- eds. 1996b. Select Documents on Indian Immigration. Mauritius, 1834 1926: Vol. 3: Living and Working Conditions under Indenture. Moka, Mauritius: Mahatma Gandhi Institute.

Dinan, Monique. 2003. Mauritius in the Making: Across the Censuses, 1846-2000. Port Louis: Nelson Mandela Centre for African Culture.

Donath, Frank. 2009. "Islamic Fundamentalism and Western Modernity among Muslims in Mauritius." In Multiple Identities in Action: Mauritius and Some Antillean Parallelisms, edited by Vinesh Y. Hookoomsing, Ralph Ludwig, and Burkhard Schnepel, 135-61. Frankfurt/Main: Lang.

Eisenlohr, Patrick. 2001. Language Ideology and Imaginations of Indianness in Mauritius. Chicago: Dissertation.

. 2002. "Language and Identity in an Indian Diaspora: 'Multiculturalism' and Ethno-linguistic Communities in Mauritius." Internationales Asienforum 33: $101-14$.

2004. "Temporalities of Community: Ancestral Language, Pilgrimage, and Diasporic Belonging in Mauritius." Journal of Linguistic Anthropology 14 (1): 81-98. doi:10.1525/jlin.2004.14.1.81.

- 2009. "An Indian Ocean "Creole Island"? Language and the Politics of Hybridity in Mauritius." In Multiple Identities in Action: Mauritius and Some Antillean Parallelisms, edited by Vinesh Y. Hookoomsing, Ralph Ludwig, and Burkhard Schnepel, 87-108. Frankfurt/Main: Lang.

Eriksen, Thomas H. 1990. "Linguistic Diversity and the Quest for National Identity: The case of Mauritius." Ethnic and Racial Studies 13 (1): 1-24. doi:10.10 80/01419870.1990.9993659.

- 1992. Us and Them in Modern Societies: Ethnicity and Nationalism in Mauritius, Trinidad and Beyond. Oslo: Scandinavian University Press.

—_ 1998. Common Denominators: Ethnicity, Nation-Building and Compromise in Mauritius. Oxford: Berg.

Hazareesingh, K. 1966. "The Religion and Culture of Indian Immigrants in Mauritius and the Effect of Social Change." Comparative Studies in Society and History 8 (2): 241-257. doi:10.1017/S0010417500004023. 1977. History of Indians in Mauritius. London: Macmillan.

Hollup, Oddvar. 1994. "The Disintegration of Caste and Changing Concepts of Indian Ethnic Identity in Mauritius.” Ethnology 33 (4): 297-316. doi:10.23 07/3773901.

- 1995. "Arya Samaj and the Shaping of 'Egalitarian' Hindus in Mauritius." Folk 36: 27-39. 
1996. "Islamic Revivalism and Political Opposition among Minority Muslims in Mauritius.” Ethnology 35 (4): 285-300. doi:10.2307/3773871.

- 2000. "Kinship and Marriage in the Construction of Identity and Group Boundaries among Indians in Mauritius." In Culture, Creation, and Procreation: Concepts of Kinship in South Asian Practice, edited by Monika Böck and Aparna Rao, 219-39. New York: Berghahn Books.

Hookoomsing, Vinesh Y. 1986. "Langue et Identité Ethnique: Les Langues Ancestrales à Maurice." Journal of Mauritian Studies 1 (2): 117-37.

Hookoomsing, Vinesh Y., Ralph Ludwig, and Burkhard Schnepel, eds. 2009. Multiple Identities in Action: Mauritius and Some Antillean Parallelisms. Frankfurt/ Main: Lang.

Jahangeer-Chojo, Amenah. 1997. "The Muslims in Mauritius: A Case Study in Ethnicity." Eastern Anthropologist 50: 165-70.

_. 2002. "Islamisation Processes among Mauritian Muslims." Internationales Asienforum 33: 116-26.

Jain, Ravindra K. 1993. Indian Communities Abroad: Themes and Literature. New Delhi: Manohar.

Kalla, A. C. 1987. “The Gujarati Merchants in Mauritius c. 1850-1900.” Journal of Mauritian Studies 2 (1): 45-65.

Kantowsky, Detlef. 2002. "Mother India ruft ihre Kinder. Bemerkungen zur Persons of Indian Origin Card besonders in Mauritius." Internationales Asienforum 33: 127-43.

Link, Hilde. 2002. "Belonging, Longing and Constructed Identity: The Temple at the Centre of Politics of Tamil Identity on Mauritius." In South Asian Migration in Comparative Perspective: Movement, Settlement and Diaspora, edited by Yasuro Hase, Hiroyuki Miyake, and Fumiko Oshikawa, 153-91. Osaka: National Museum of Ethnology.

Ludwig, Ralph, and Burkhard Schnepel. 2009. "Some Ideas on Communication, Culture and Society in Mauritius: Multiple Identities in Action.” In Multiple Identities in Action: Mauritius and Some Antillean Parallelisms, edited by Vinesh Y. Hookoomsing, Ralph Ludwig, and Burkhard Schnepel, 9-16. Frankfurt/Main: Lang.

Lutz, Wolfgang, ed. 1994. Population - Development-Environment: Understanding their Interactions in Mauritius. Berlin: Springer.

Mathur, Raj. 1997. "Parliamentary Representation of Minority Communities: The Mauritian Experience." Africa Today 44: 61-82.

McPherson, Kenneth. 2009. "Mauritius: Model and Mirror of History." In Multiple Identities in Action: Mauritius and Some Antillean Parallelisms, edited by Vinesh Y. Hookoomsing, Ralph Ludwig, and Burkhard Schnepel, 31-44. Frankfurt/Main: Lang.

Mehta, S. R. 1995. "Power Dynamics of Indian Immigrants in Mauritius: A Study in Ethnic Relations.” Indian Anthropology 25: 1-11. 
Meisig, Marion. 1999. "Tamilischer Hinduismus auf Mauritius. Der MīnākṣīTempel in Port Louis." Mitteilungen für Anthropologie und Religionsgeschichte 14: 251-74.

Miles, William F. S. 1999. "The Creole Malaise in Mauritius.” African Affairs 98 (391): 211-28. doi:10.1093/oxfordjournals.afraf.a008008.

Ministry of External Affairs. 2002. "Report of the High Level Committee on Indian Diaspora.” New Delhi: Government of India. Accessed October 02, 2017. http://indiandiaspora.nic.in/contents.htm.

Mukonoweshuro, Eliphas G. 1991. "Containing Political Instability in a PolyEthnic Society: The Case of Mauritius." Ethnic and Racial Studies 14 (2): 199-224. doi:10.1080/01419870.1991.9993707.

Nave, Ari. 2000. "Marriage and the Maintenance of Ethnic Group Boundaries: The Case of Mauritius." Ethnic and Racial Studies 23 (2): 329-52. doi:10.1080/014198700329079.

Nirsimloo-Anenden, Ananda D. 1990. The Primordial Link: Telugu Ethnic Identity in Mauritius. Moka, Mauritius: Mahatma Gandhi Institute.

Prakash, Gyan. 1992. The World of the Rural Labourer in Colonial India. Delhi: Oxford University Press.

Ramsurrun, Pahlad, ed. 2001. Glimpses of the Arya Samaj in Mauritius. New Delhi: Sarvadeshik Prakashan Ltd.

Royle, Stephen A. 1995. "Population and Resources in Mauritius." Geography Review 8: 35-41.

Schnepel, Burkhard. 2005. "Inder auf Reisen." In Bewegliche Horizonte: Festschrift zum 60. Geburtstag von Bernhard Streck, edited by Katja Geisenhainer and Katharina Lange, 165-84. Leipzig: Leipziger Universitätsverlag.

—_ 2009. "Two Beaches: The Globalization of Mauritian Waterfronts." In Multiple Identities in Action: Mauritius and Some Antillean Parallelisms, edited by Vinesh Y. Hookoomsing, Ralph Ludwig, and Burkhard Schnepel, 287317. Frankfurt/Main: Lang.

Schnepel, Burkhard, and Cornelia Schnepel. 2008. “ „Finger weg von unserem Strand“: Tourismus auf einer multikulturellen „Paradiesinsel“ (Mauritius) im Indischen Ozean.” AAS Working Papers in Social Anthropology 4. http:// epub.oeaw.ac.at/0xc1aa500e_0x001c98fb.pdf.

__ 2009a. "Die Globalisierung des Strandes: Das Beispiel Mauritius." In Zwischen Aneignung und Verfremdung: Ethnologische Gratwanderungen, edited by Volker Gottowik, Holger Jebens, and Editha Platte, 489-509. Frankfurt/ Main: Campus-Verl.

. 2009b. "The Mauritian Séga: Performing Identity in a Multi-Cultural Setting." In Multiple Identities in Action: Mauritius and Some Antillean Parallelisms, edited by Vinesh Y. Hookoomsing, Ralph Ludwig, and Burkhard Schnepel, 275-86. Frankfurt/Main: Lang. 
2011. "From Slave to Tourist Entertainer: Performative Negotiations of Identity and Difference in Mauritius." In Islanded Identities: Constructions of Postcolonial Cultural Insularity, edited by Maeve McCusker and Anthony Soares, 109-26. Amsterdam: Rodopi.

Srebrnik, Henry. 1999. "Ethnicity and the Development of a 'Middleman' Economy on Mauritius: The Diaspora Factor." The Round Table 88 (350): 297-311. doi:10.1080/003585399108162.

- 2000. "Can an Ethnically-Based Civil Society Succeed? The Case of Mauritius." Journal of Contemporary African Studies 18 (1): 7-20. doi:10.1080/025890000111940.

Tinker, Hugh. 1974. A New System of Slavery: The Export of Indian Labour Overseas 1830-1920. London: Published for the Institute of Race Relations by Oxford University Press.

van der Veer, Peter, ed. 1995. Nation and Migration: The Politics of Space in the South Asian Diaspora. Philadelphia: University of Pennsylvania Press.

Vertovec, Steven. 2000. The Hindu Diaspora: Comparative Patterns. London: Routledge. 